\title{
Cholesterol-Lowering and Hepatoprotective Effect of Fruit Juice Extract of Azadirachta indica on Plasmodium berghei Infected Mice
}

\author{
I.O. Igwenyi ${ }^{1 *}$, A.C. Eze $^{2}$, P.M. Aja ${ }^{1}$, S.O. Elom ${ }^{3}$, A.J. Uraku ${ }^{1}$, \\ J.N. Awoke ${ }^{1}$ and N.A. Obasi ${ }^{3}$ \\ ${ }^{1}$ Department of Biochemistry, Ebonyi University, Abakaliki, Ebonyi State, Nigeria \\ ${ }^{2}$ Department of Biochemistry, Federal University, Oye-Ekiti, Ekiti State, Nigeria \\ ${ }^{3}$ Department of Medical Biochemistry, Federal University, Ndufu-Alike Ikwo, Ebonyi State, \\ Nigeria \\ *Corresponding author
}

\begin{tabular}{|c|c|}
\hline & A B S T R A C T \\
\hline & \multirow{6}{*}{$\begin{array}{l}\text { The effect of fresh juice extract of Azadirachta indica on lipid profile and hepatic function } \\
\text { of Plasmodium berghei infected albino mice were investigated. Thirty adult male mice } \\
\text { were placed in five groups of six mice each, acclimatized for } 7 \text { days and used for the study. } \\
\text { Group A was normal control and had free access to feed and water while groups B to E } \\
\text { were infected with Plasmodium berghei, and confirmed of parasitamia on the third day. } \\
\text { Groups } \mathrm{C}, \mathrm{D} \text { and } \mathrm{E} \text { were further given standard anti malaria drug }(5 \mathrm{mg} / \mathrm{kg} \text { body weight of } \\
\text { Artesunate), } 4.3 \mathrm{ml} / \mathrm{kg} \text { and } 8.6 \mathrm{ml} / \mathrm{kg} \text { of fruit juice extract respectively for fourteen days } \\
\text { and sacrificed. It was observed that parasitemia caused a marked increase in the activities } \\
\text { of liver enzymes and in the levels of total protein, LDL-C and total cholesterol The result } \\
\text { revealed that treatment with a standard drug and fruit juice extract significantly reduced } \\
\text { (P<0.05) the activities of AST, ALT and ALP. Parasitemia increased the level of total } \\
\text { bilirubin significantly (P }<0.05 \text { ) but treatment with standard drug and fruit juice extract } \\
\text { lowered the level of the total bilirubin significantly ( }<0.05 \text { ). Investigation of the effect on } \\
\text { lipid profile revealed that the fruit juice extract has cholesterol lowering effect with a } \\
\text { significant increase ( }<0.05 \text { ) in the level of HDL-cholesterol and a significant decrease } \\
\text { (p }<0.05 \text { ) in the level of total cholesterol. However, there was no significant effect (p }>0.05) \\
\text { on the level of triacylglycerol upon treatment with the juice extract. The result has shown } \\
\text { that fruit juice extract of Azadirachta indica has hepatoprotective property and lipid } \\
\text { lowering (hypolipidemic) effect and may find useful application in the management of } \\
\text { hepatic damage, oxidative stress and cardiovascular diseases. }\end{array}$} \\
\hline Keywords & \\
\hline $\begin{array}{l}\text { Fruit juice extract, } \\
\text { Azadirachta indica, } \\
\text { Liver enzymes, } \\
\text { Plasmodium } \\
\text { berghei, } \\
\text { Cholesterol, Lipid } \\
\text { profile. }\end{array}$ & \\
\hline Article Info & \\
\hline $\begin{array}{l}\text { Accepted: } \\
\text { 10 July } 2017 \\
\text { Available Online: } \\
\text { 10 September } 2017\end{array}$ & \\
\hline & \\
\hline
\end{tabular}

\section{Introduction}

Malaria has a broad distribution in both the subtropical and tropical regions, with many areas of the tropics endemic for the disease. The countries of sub-Saharan Africa account for the majority of all malaria cases, with the remainder mostly clustered in India, Brazil, Afghanistan, Sri Lanka, Thailand, Indonesia,
Vietnam, Cambodia, and China (Snow et al., 1999). Malaria is a mosquito borne disease of humans caused by protozoan parasite of the genus Plasmodium. It is transmitted from one human to another by the bite of an infected female anopheles mosquito. It is widespread in tropical and sub-tropical regions, including 
the sub-Sahara Africa, Asia and the Americans (Clark and Cowden, 2003) and a major cause of mortality and morbidity worldwide. These parasites have a complex life cycle in their mosquito vector and vertebrate hosts and have evolved some level of drug resistance. The primary factors contributing to the resurgence of malaria are the appearance of drug-resistant strains of the parasite, the spread of insecticide-resistant strains of the mosquito and the lack of licensed malaria vaccines of proven efficacy (WHO, 2016).

Once in the human bloodstream, $P$. falciparum sporozoites for instance, reach the liver and penetrate the liver cells (hepatocytes) where they remain for 916 days and undergo asexual replication known as exo-erythrocytic schizogony. The mechanism of targeting and invading the hepatocytes is not yet well understood, but studies have shown that sporozoite migration through several hepatocytes in the mammalian host is essential for completion of the life cycle (Mota et al., 2001). Uncomplicated malaria is diagnosed when symptoms are present, but there are no clinical or laboratory signs to indicate a severe infection or the dysfunction of vital organs. Individuals suffering from this form can eventually develop severe malaria if the disease is left untreated, or if they have poor or no immunity to the disease. Severe malaria is defined by clinical or laboratory evidence of vital organ dysfunction. This form has the capacity to be fatal if left untreated (CDC, 2015). This could be as a result of reactive oxygen species that are generated by the parasitic infection through Fenton and Weiss reaction.

Malaria is directly responsible for one in five childhood deaths in Africa and indirectly contributes to illness and deaths from other diseases (WHO, 1999). Pregnant women and children under five years of age are most vulnerable. In the absence of an effective vaccine, the fight against malaria depends on chemotherapy as well as the reduction and prevention of breeding and anopheles contacts with humans (Winstainly, 2000). Therefore to combat malaria, new knowledge, products and tools especially new drugs are urgently needed (Omulokoli et al., 1997). Traditional methods of treatment and control could be promising sources of potential anti-malaria drugs (Wright and Phillipson, 1990).

Azadirachta indica is locally known as neem. It is a tree in the mahogany family of meliaceae. It is native to India, Bangladesh, Thailand, Nepal and also grows well in tropical and sub-tropical regions. Neem is the most important medicinal plant that has been declared worldwide as the "tree of the $21^{\text {st }}$ century" by the United Nations. The tender shoots and flowers of the neem tree are eaten as a vegetable in India. The neem tree plant has anthelmintic, antifungal, antidiabetic, antibacterial, antiviral, contraceptive and sedative properties. Neem leaves have also been used to treat skin diseases like eczema and psoriasis (Porter, 2006). The fruit juice extract has not been reported as having medicinal value, though it has been reported that the fruit juice extract has great biochemical composition (Igwenyi et al., $2014 b$ ), hence this investigation.

\section{Materials and Methods}

Mature and fresh ripe fruits of Azadirachta indica were harvested from $2^{\text {nd }}$ Baze Bar and Restaurant, Abakaliki, Ebonyi State, Nigeria, where it is planted as a shade tree. The fruits were washed with distilled water and the fresh juice extracted using electric juice extractor. All the chemicals were of analytical grade.

Adult, male mice were obtained from the Animal House of the Faculty of Veterinary 
Medicine, University of Nigeria, Nsukka, Nigeria. They were acclimatized for 7 days in aluminum cages in the Animal House of the Department of Biochemistry, Ebonyi State University, Abakaliki, before treatment. During this period, they were fed with commercial mice pellets. Clean water was provided daily and animals were allowed free access to food and water. At the end of the seven (7) days acclimatization period, the animals were weighed and randomly placed into (5) different groups of six (6) mice in each. Each group was kept in a different cage while the weights were used to determine the equivalent dose of $4.3 \mathrm{ml}$ and $8.6 \mathrm{ml} / \mathrm{kg}$ body weight corresponding and equivalent to $300 \mathrm{ml}$ (table glass volume) and $600 \mathrm{ml}(2 \mathrm{x}$ table glass volume) per $70 \mathrm{~kg}$ of adult human.

A quantity (1ml) of plasmodium infected blood was dissolved in normal saline. Using a syringe, the dissolved Plasmodium berghei was injected via intraperitoneal route into the mice. The mice were allowed for 72 hours before blood samples were collected from the tail for microscopic examination and confirmation of parasitemia. Only rats that had plasmodium parasite were used for the study.

Group A Swiss albino mice were fed on normal feed (pellets) and allowed free access to water. Groups B to E mice were infected with Plasmodium berghei (NK 65) and used for the study. Group B mice were left untreated as positive group and had free access to feed and water. Group $\mathrm{C}$ animals were treated with $5 \mathrm{mg} / \mathrm{kg}$ body weight of Artesunate and had access to feed and water.

Groups D and E were treated with the fruit juice extract of Azadirachta indica twice daily through oral intubation according to their body weight at doses of $4.3 \mathrm{ml} / \mathrm{kg}$ and 8.6 $\mathrm{ml} / \mathrm{kg}$ body weight respectively. The animals were treated for fourteen (14) days. Blood samples were collected from the mice through cardiac puncture and the serum used for the analysis. The ALT, AST and ALP were measured by colorimetric methods as described by Reitman and Frankel (1957) while the lipid profile was measured using spectrophotometric methods described by Pearson et al., (1953) and Rice (1970). Data were expressed as mean \pm standard deviation and subjected to one way analysis of variance (ANOVA at $95 \%$ confidence limit) followed by post- hoc test and $\mathrm{p}<0.05$ was considered significant (Fig. 3).

\section{Results and Discussion}

The effect of the Azadirachta indica fruit juice extract on the activities of liver enzymes in parasitized mice

There was an increase in AST. The mean value of group $\mathrm{A}, \mathrm{C}, \mathrm{D}$ and $\mathrm{E}$ were significantly lower $(p<0.05)$ than group $B$, indicating a decrease in the activity of AST relative to the positive control. There was no significant difference (P> 0.05) in the standard drug group compared to normal and the test groups.

There was a significant increase $(\mathrm{P}<0.05)$ in the positive control but treatment with standard drug and fruit juice extract yielded a similar trend in the reduction of ALT activity.

There was a significant increase in the positive control $(\mathrm{P}<0.05)$, while treatment with fruit juice extract decreased the activity $(\mathrm{P}<0.05)$ significantly (Figs. 1 and 2$)$.

The effect of the Azadirachta indica fruit juice extract on the level of bilirubin in parasitized mice

Parasitemia increased the level of total bilirubin significantly $(\mathrm{P}<0.05)$ while treatment with standard drug and fruit juice 
lowered the level of the total bilirubin to a level of no significant difference with normal control group (Fig. 4).

The effect of the Azadirachta indica fruit juice extract on the lipid profile of parasitized mice

The mean value of group B, D and E were significantly higher than group $\mathrm{A}$ and $\mathrm{C}$. There was no significant difference between the test groups and the positive control $(\mathrm{P}>0.05)$.

There was an increase in the level of HDL $(\mathrm{P}<0.05)$ but the increase was most significant in the group treated with the standard drug.

The level of cholesterol significantly increased in the positive control while treatment with standard drug and fruit juice reduced the level significantly relative to positive group. The result showed that the fruit juice has cholesterol lowering effect.

The result revealed that there was no significant effect $(\mathrm{P}>0.05)$ on the level of triacylglycerol in all the groups. Thus, parasitemia and treatment has no significant effect on the triacylglycerol. Neem products are believed to be anti-helmintic, antifungal, antidiabetic, anti-bacteria, antiviral, contraceptive and sedative and antiplasmodia. Neem leaves, bark and seed extracts have been used for centuries in India in ethnomedicine and ethnoveterinary medicine (Biswas et al., 2002; Subapriya et al., 2005). Hence, this investigation was carried out to ascertain possible antiplasmodia effect of fruit juice extract of Azadirachta indica. Drugs usually present the patient/receiver with side effects and they are non-nutritious. Their metabolism and clearance places a metabolic burden on the system, leading sometimes to toxic and side effects. Sometimes, drugs are accompanied with multivitamins and blood capsules to cushion their side effects. The fruit juice of Azadirachta indica can also function as a source of useful nutrients and unusually rich in plant protein (Igwenyi et al., 2014b). It then becomes novel for a dual role of having a therapeutic value and a nutritional potential when used for anti-plasmodal treatment. Earlier studies on the biochemical compositions of Azadirachta indica fruit juice revealed high nutritional endowment, presence of bioactive components and high level of proteins and vitamins (Igwenyi et al., 2014b). Consequently, the effect of Azadirachta indica fruit juice extract on the lipid profile and hepatic function was determined.

Fig.1 Effect of fruit juice of Azadiracta indica on AST level of mice

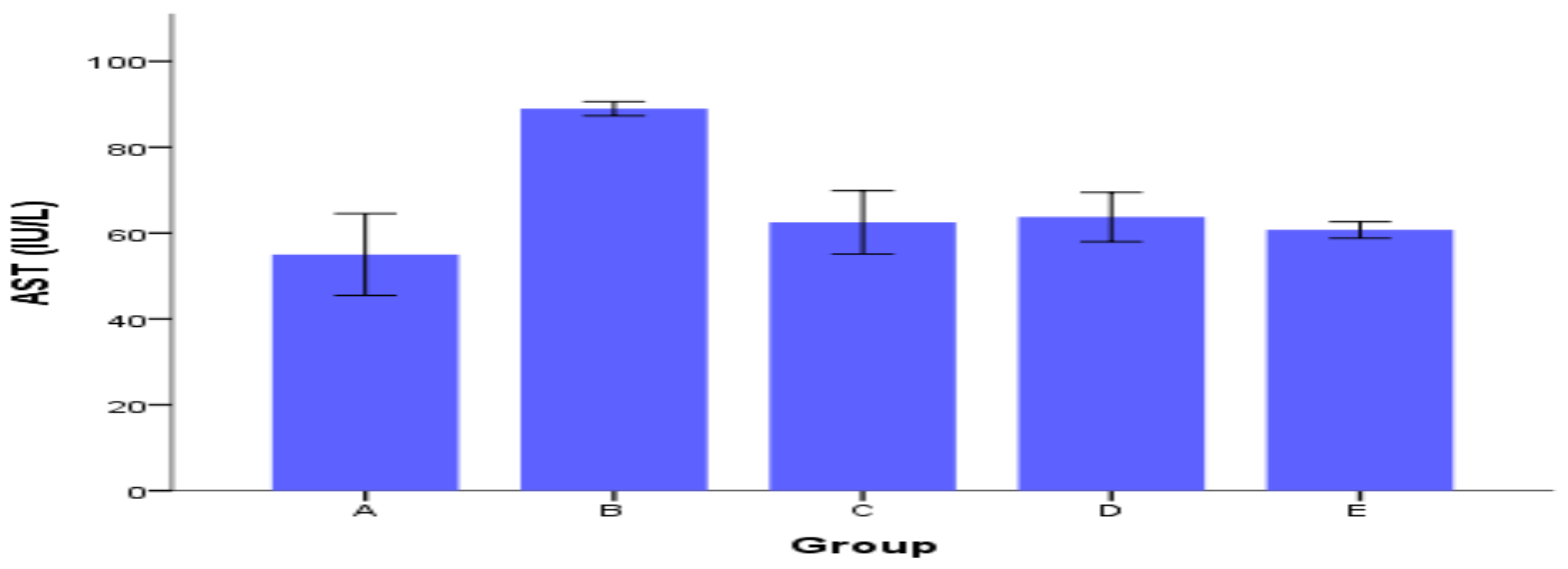


Fig.2 Effect of fruit juice of Azadiracta indica on ALT level of mice

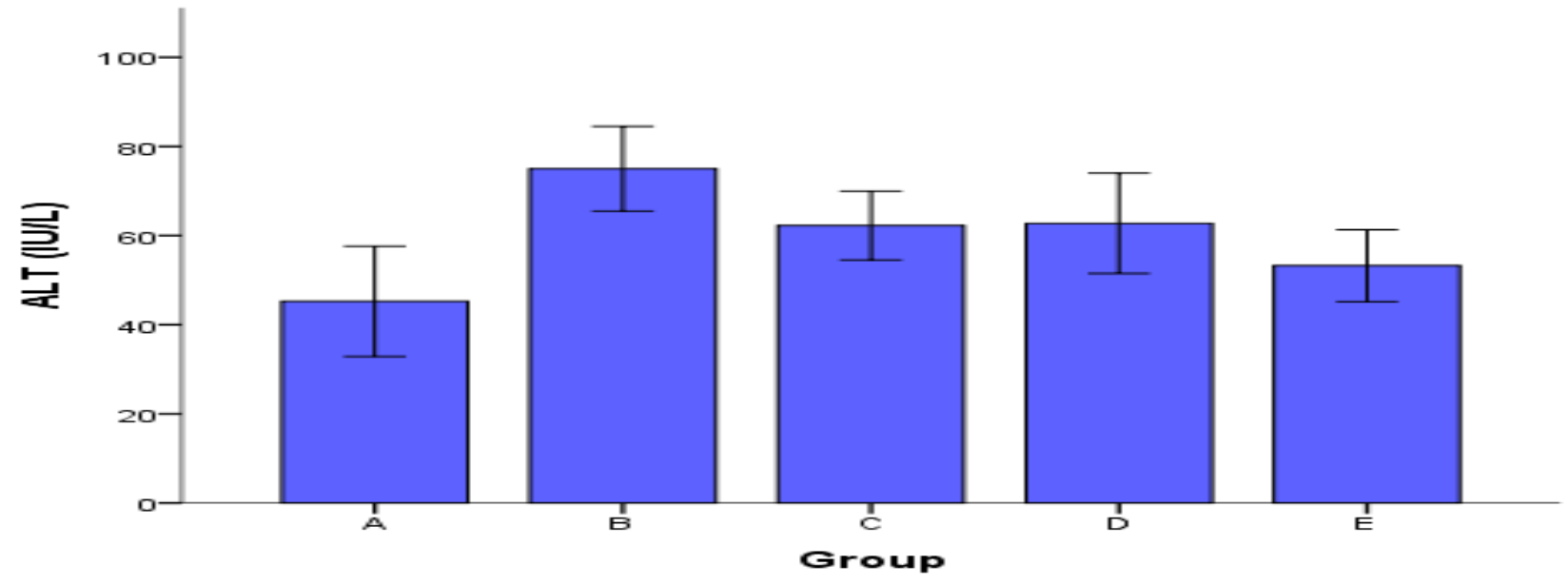

Fig.3 Effect of fruit juice of Azadiracta indica on ALP level of mice

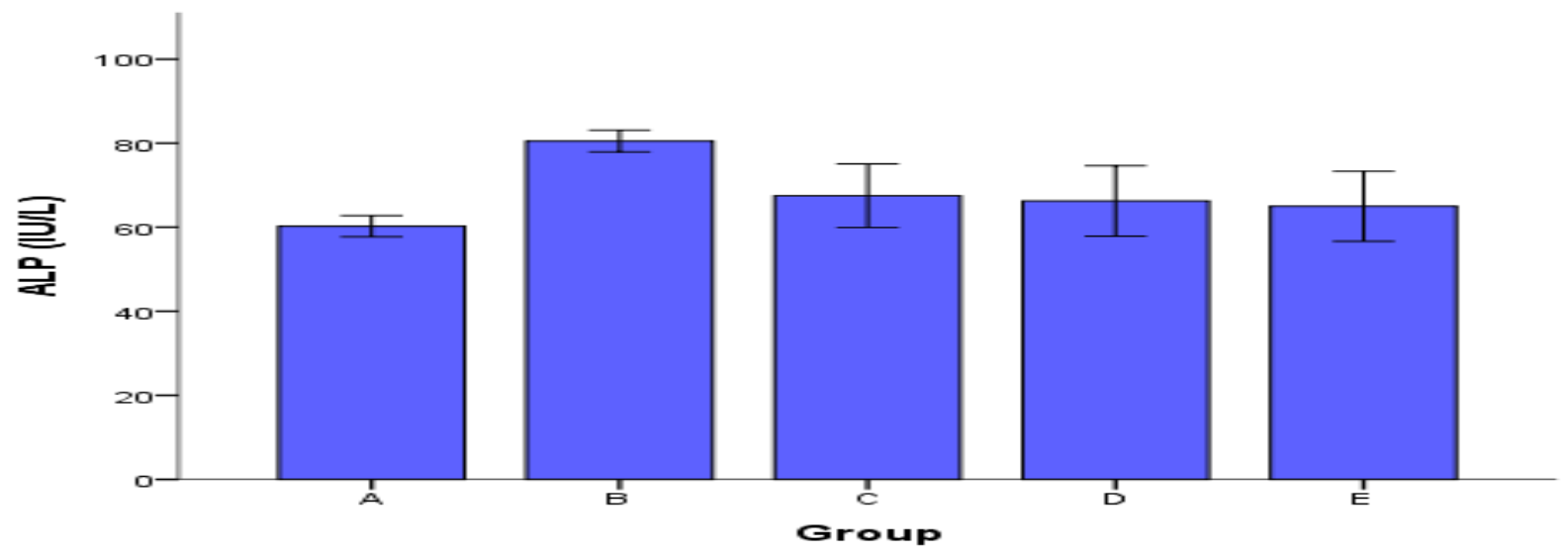

Fig.4 Effect of fruit juice of Azadiracta indica on Total bilirubin level of mice

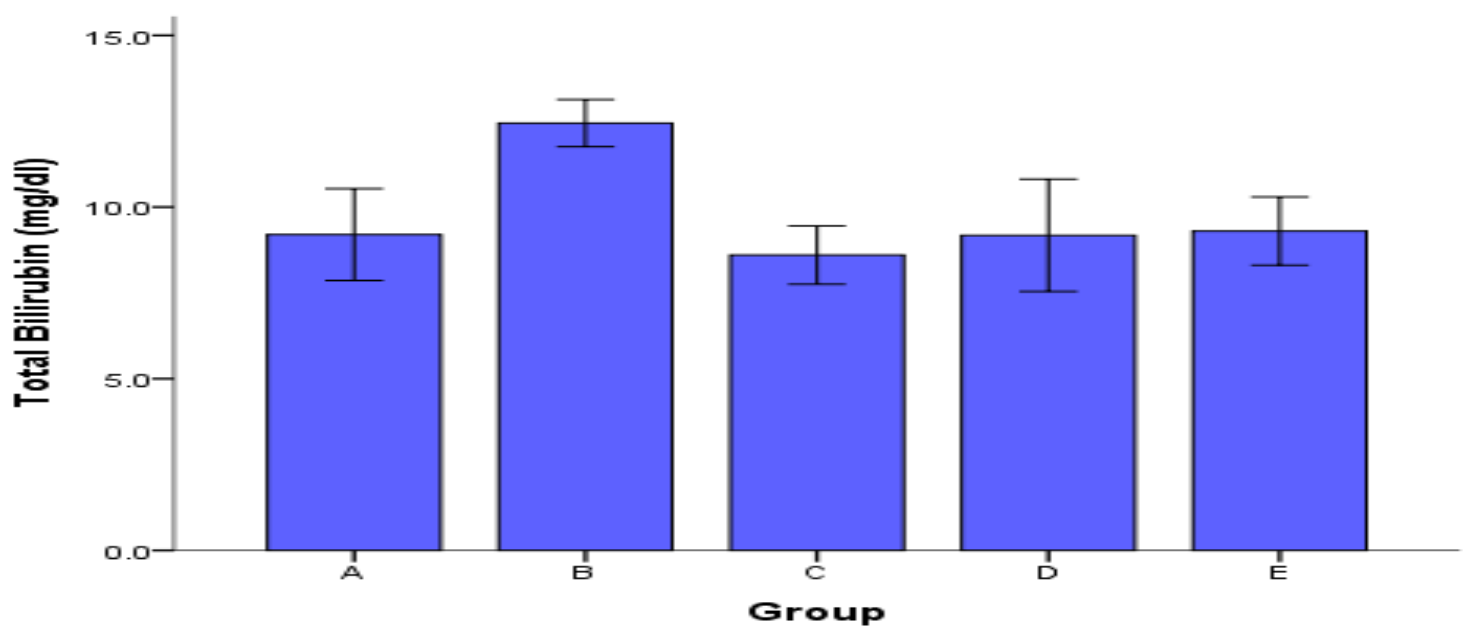


Fig.5 Effect of fruit juice of Azadirachta indica on LDL level of mice

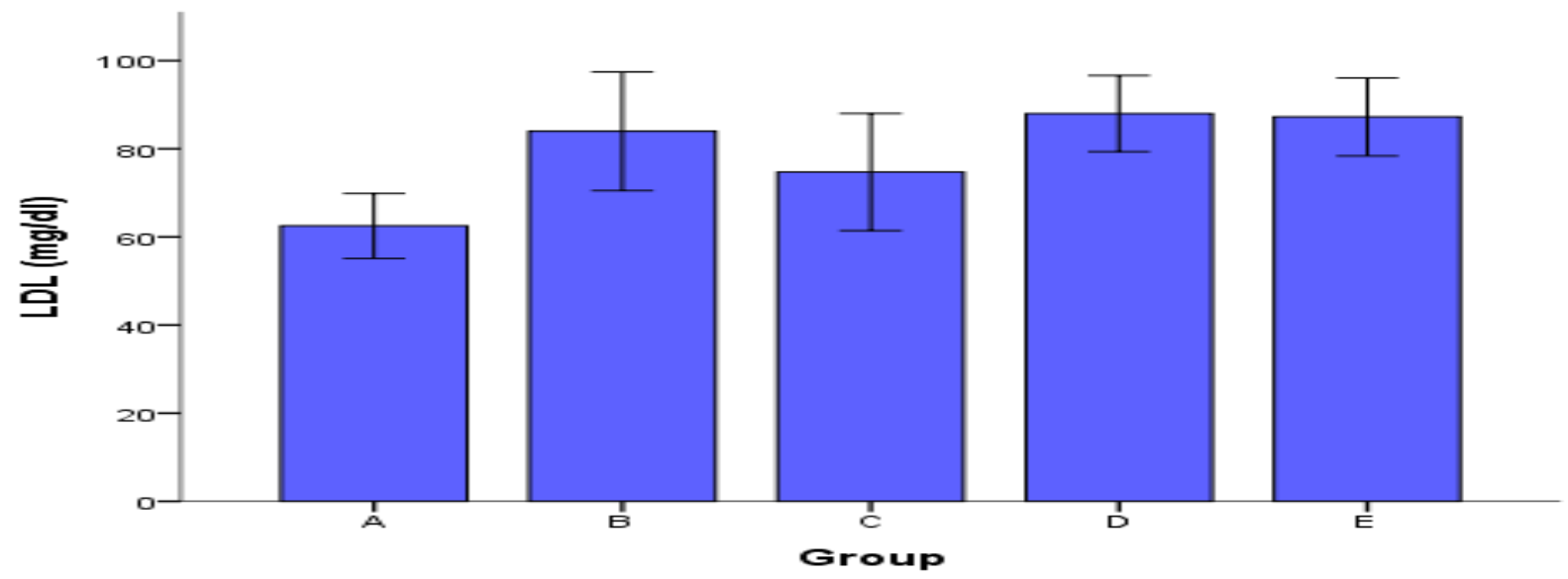

Fig.6 Effect of fruit juice of Azadiracta indica on HDL level of mice

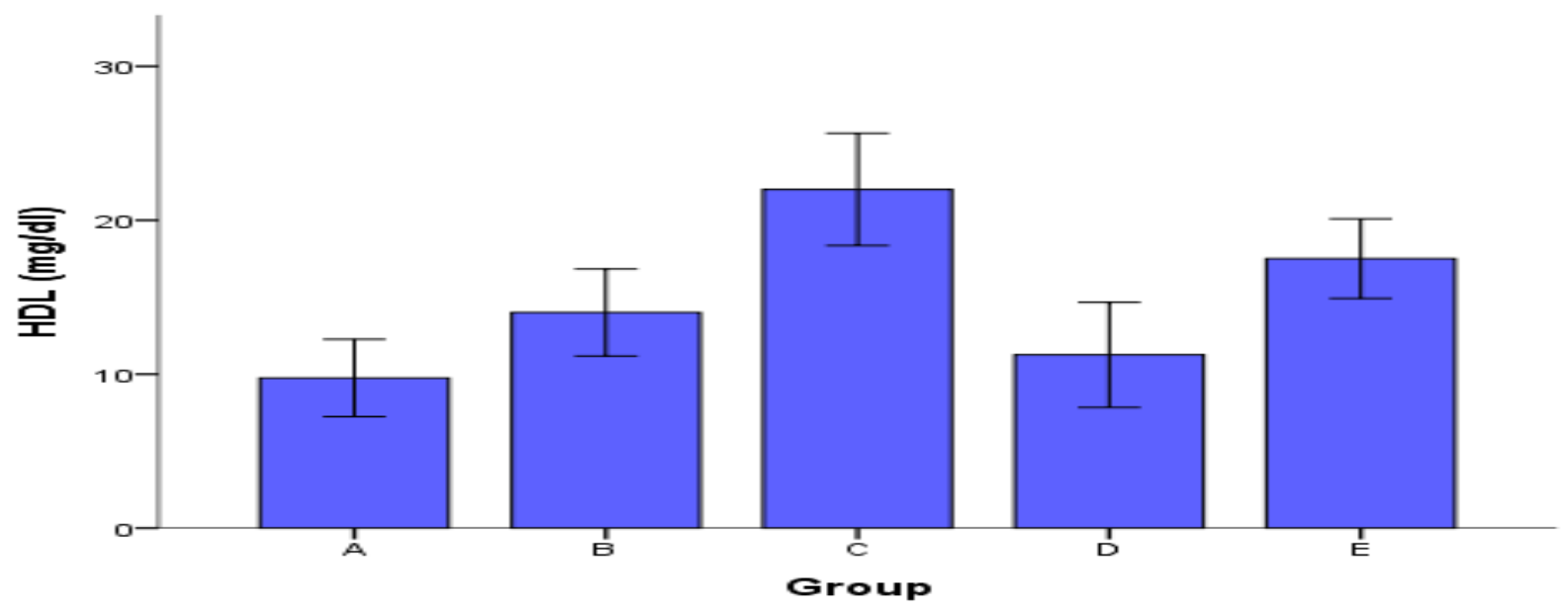

Fig.7 Effect of fruit juice of Azadiracta indica on Cholesterol level of mice

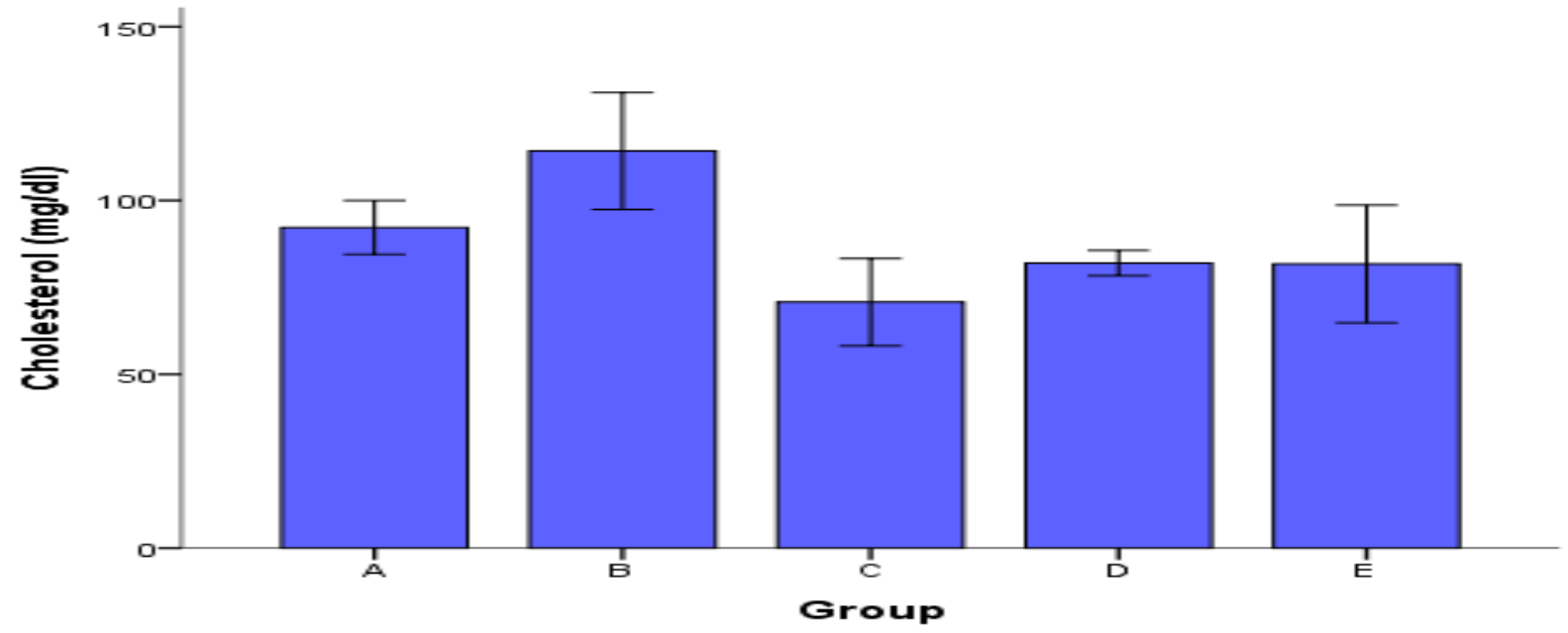


Fig.8 Effect of fruit juice extract of Azadiracta indica on TAG level of mice

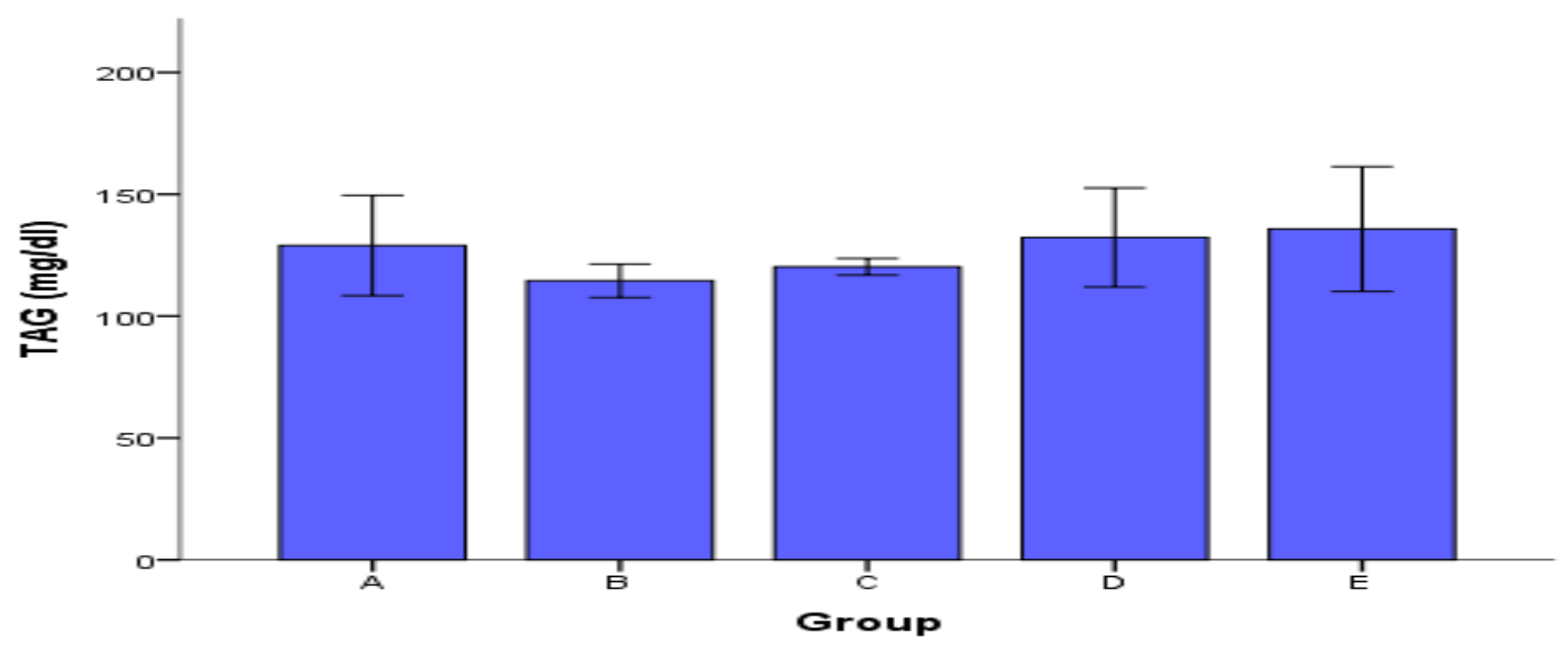

It was observed that Plasmodium berghei infection caused alteration in liver functions which was observed in the increased activities of AST, ALT and ALP. Parasitemia also caused a remarkable increase in the levels of total bilirubin, LDL-C and total cholesterol (Fig. 5 and 7). In mammals, some internal organs and tissues are usually affected by infections and disease conditions but clinical assessment of the extent of toxicity is achieved by measuring the activities of certain enzymes that catalyze biochemical reactions in the tissue (Igwenyi et al., 2014a) as well as the level of other parameters that may be affected by the infection. Malaria and parasitemia are usually associated with liver and erythrocytic stages of plasmodium development, leading to damage to hepatic cells and lysis of the red blood cells. Damage to hepatic cells will lead to increased activity of liver enzymes (transaminases) while increased red blood cell lysis will cause a significant increase in the level of total bilirubin in the serum. However, treatment with artesunate and fruit juice extract caused a significant decrease $(p<0.05)$ in the activities of AST, ALT and ALP. This could be as a result of possible antioxidant property of the fruit juice extract due to its endowment with antioxidant vitamins (Igwenyi et al., 2014b).
It was also observed that treatment with both artesunate and the fruit juice extract caused a significant decrease $(p<0.05)$ in total bilirubin and total cholesterol while the level of HDL$C$ increased $(p<0.05)$ significantly (Fig. 6). Decrease in total bilirubin could be as a result of increased conjugative power of the liver in increased production of conjugated bilirubin for excretion. The result of the lipid profile and the liver enzymes activity of the juice extracts are comparable to the standard drug group and the result showed no significant difference ( $p>0.05)$. This result is comparable to the effect of aqueous extract of Gongronema latifolium (Offor et al., 2012) and administration of seed extracts of Moringa oleifera (Aja et al., 2014) (Fig. 8).

Fruit juice extracts have been known to have nutritional properties and serve only nutritional functions to birds, bats and rodents. Fruit juice extracts contain nutrients such as proteins, carbohydrates, lipids, as, fiber and mineral water as well as minerals, vitamins and phytochemicals. It then implies that fruit juice may be applied for therapeutic purposes and will attenuate damage to cells and tissues as well as provide energy for growth, recovery and development. Thus, this work observed for the first time, possible 
medicinal value and possible therapeutic application of Azadirachta indica fruit juice extract due to its potential as a lipid lowering agent and hepatoprotective properties in Plasmodium berghei infected mice.

\section{References}

Aja, P. M., Nwachukwu, N., Ibiam, U. A., Igwenyi, I. O. and Onu, P. N. 2013. Comparative Evaluation of Transaminases and Alkaline Phosphatase Activities in Albino Rats Administered Aqueous, Ethanolic and Methanolic Extracts of Moringa oleifera Seeds Locally Grown in Abakaliki, Nigeria. Journal of Biological and Chemical Research, 31(1): 164 - 181.

Ansari, M. A., and Razdan, R. K. 1996. Operational feasibility of malaria control by burning neem oil in kerosene lamp in Beel Akarpin village district Ghaziasao, India. Indian Journal. Of Maloriology 33: 81-87.

Biswan, K., Banergee, R. K. and Bandyopadhyay, U. 2002. Biological activities and medicinal properties of neem (Azadirachta indica). Current Science, 82: 1336-1345.

Biswas, K., ChaHopadhyay, I., Banerjee, R. K. and Bandyopadhyay, U. 2002. Biological Activities and medicinal properties of neem (Azadirachta indica). Current science. 82(11): 13361345

Chessburgh, C., 2000. District Laboratory Practice in Tropical Countries. Cambridge University Press. Pg. 90-98.

Dua, V. K., Negpal, B. N. and Sharma, V. P. 1995. Repellant action of neem cream against mosquitoes. Indian Journal of malarialogy. 32:47-53.

Ekanem, O. I., 1971. Has Azadirachta indica (dogonyaro) any anti-malarial activity? Niger Medical Journal malarialogy. 8:
8-11.

Howard, A, F., Adongo, E. A., Hassandi, A., Omlin, F. X., Wanjoya, A. and Zhou, G. 2009. Laboratory evaluation of the acqeous extract of Azadirachta indica (neem) wood chippings on anopheles gambiae S.S (Diptera: cuicida) mosquitoes. Journal of Medical Entamology 46:107-114.

Igwenyi, I. O., Aboh, N., Nwachukwu, N., Ibiam, U. A., Offor, C. E., Aja, P. M. and Agbafor, K. N. 2014a. Effect of Baygon Insecticides on the Activities of Total, Alkaline and Acid Phosphatases of Selected Tissues of Albino Rats. IOSR Journal of Pharmacy and Biological Sciences, 9(3) v: 41- 43.

Igwenyi, I. O., Nwigbo, N. O., Nwokike, J. C. and Awoke, J. N. 2004b. Biochemical compositions of Azadirachta indica fruit juice. World Applied Sciences Journal, 32(2): 239-242.

Lewis, R. A., Bhide, N. K.and Mehta, D. J. 1958. Diabetic and Diauretic action of sodium nimbidinate in Azadirachta indica leaf. Indian Journal of medical Science. 12:141-145.

Mbah, A. U., Udeinya, I. J., Shu, E. N., Chijioke, C. P., Nubila, T., Udeinya, F., Muobike, A., Mmuobieri, T. and Obioma, M. S. 2007. Fractionated leaf extract is safe and increases CD4 cells levels in HIV/AIDS patients. American Journal of. Ther. 14(4):369-374.

Nwafor, S. V., Akah, P. A., Okoli, C. O, Onyirioha, K. C and Nwosu, C. S. 2003. Interaction between chloroquine sulphate and aqueous extract of Azadirachta indica in rabbits. Acta Pharm. 53:305-331.

Offor, C. E., Aluanya, U. P., Igwenyi, I. O., Ibiam, U. A., Elom, S. O. and Agbafor, K. N. 2012. Effect of Aqueous Extract of Gongronema latifolium Leaves on Lipid Profile in Albino Rats. Continental Journal of Food Science 
and Technology, 6(2): $20-22$.

Pearson, S., Stearn, J. and McGavat, T. A. 1951. Analytical Chemistry. Journal of Clinical Endocrinology, 6: 66 - 70

Porter, J. R., Eyberger, A. I., Dondapati, R., 2006. Endophyte Fungal Isolates from Podophyllum Peltatum produce podophyllotoxin. Journal of nature Production. 69:1121-1124.

Reitman, S. and Frankel, S. 1957 b. Assay of transaminase. American Journal of Clinical Pathology, 28: 56 - 63

Schmutteer, H., Ascher, K. R. S., Isman, M. B. 1995. The neem tree: Azadirachta indica A Juss and other meliaceous plants. Weinheim, Germany, Pg 1-3.

Stix, G., 1992. Village pharmacy. The neem tree yields products from pesticides to soup. Science America. 266: 132 - 135.

Subapriya, R., and Hagini, S., 2005. Medicinal properties of neem leaves: current Medical chemical anticancer agents. 5(2): 149.

Tiez, N.W., 1970) Text book of Clinical Chemistry, $2^{\text {nd }}$ Edition. Burtis, C.A., Ashwood, E.R., W.B. Saundas Company, Philadephia. Pp 751.

Udeinya, I. J., 1993. Antimalarial activity of Nigerian neem leaves. Trans Royal Society of Tropical Medicine Hygiene, 8: 387 - 471.

Udeinya, I. J., Brown, N., Shu, E. N., Udeinya, F. I and Quakeyie, F. 2006.
Fractions of antimalarial neem-leaf extract have activities superior to chloroquine and are gametocyticidal. Annals of Tropical Medical Parasitology. 100(1): 17 - 22.

Udeinya, I. J., Shu, E. N., Chijioke, C. P., Mbah, A. U. 2004. An anti- malarial extract from neem leaves is antiretroviral. Trans.Royal Society of Medical Hygiene. 98: 453 - 457.

Udeinya, I. J., Shu, E. N., Quakeyie, F. and Ajayi, F. O 2008. An anti- malarial neem- leaf extract has both schizonticidal and gametocytocidal activities. American Journal of Therapeutics. 15:108-110.

Van Slyke, S.A., and Tang, C.W. 1987. Induced termination of pregnancy by purified extract of Azadirachta indica (Neem) mechanisms involved. American Journal of Reproductive Immunology. 37(6): 485 - 491.

World Health Organization 2008. World malaria report.WHO/HTM/GMP/2008. pg 1-190.

Zafar, J., Bhatti, F., Akhtar, N., Rasheed, U., Bashir, R., Humayun, S., Waheed, A., Younus, F., Nazar, M. and Umaima L. 2011. Prevalence and risk factors for diabetes mellitus in a selected urban population of a city in Punjab. Journal of Pakistan Medical Association. 61(1):40-46.

\section{How to cite this article:}

Igwenyi, I.O., A.C. Eze, P.M. Aja, S.O. Elom, A.J. Uraku, J.N. Awoke and Obasi, N.A. 2017. Cholesterol-Lowering and Hepatoprotective Effect of Fruit Juice Extract of Azadirachta indica on Plasmodium berghei Infected Mice. Int.J.Curr.Microbiol.App.Sci. 6(9): 3367-3375. doi: https://doi.org/10.20546/ijcmas.2017.609.415 